\title{
Maceration stage in corrosion cast specimen procedure in anatomy: a minireview
}

\author{
Z. Domagała1', J. Domański², N. Smyczek², C. Galk² \\ ${ }^{1}$ Division of Anatomy, Department of Human Morphology and Embryology, Wroclaw Medical University, Wroclaw, Poland \\ ${ }^{2}$ Clinical and Dissecting Anatomy Students Scientific Club, Wroclaw Medical University, Wroclaw, Poland
}

[Received: 2 October 2021; Accepted: 21 October 2021; Early publication date: 5 November 2021]

\begin{abstract}
The etching stage of the corrosive preparation is a crucial element of creating a high quality anatomical specimen, which can be a source of scientific knowledge and support the teaching process. Nowadays, thermal techniques such as microwave cooking, enzymatic corrosion, and chemical corrosion are used. Living organisms can also be used for tissue maceration. Interactions between the corrosive substance and the filler carry a risk of failure; thus, choosing the correct method is key to the success of this technique. In this paper, we have reviewed the latest literature in order to present the strengths and weaknesses of currently used corrosion techniques. We proposed a definition of an ideal corrosive medium and compared the available techniques of etching corrosive preparations with a hypothetical perfect medium. (Folia Morphol 2022; 81, 4: 825-833)
\end{abstract}

Key words: corrosive cast specimen, maceration, corrosion, etching

\section{INTRODUCTION}

Corrosion technique is one of the most remarkable techniques enabling three-dimensional (3D) visualisation of particular anatomical structures. Its usefulness has been demonstrated in many scientific papers on human and animal anatomy $[8,12,19,21$, 55]. This method is usually used to accurately assess the architecture of vessels. In this case, its particular usefulness is related to the possibility to evaluate an organ in vitro (Fig. 1), particularly when there are contraindications for in vivo evaluation [9]. On the other hand, there are many works that use this technique to create micro-specimens that will then be evaluated in electron microscopy. In the case of microanatomy, for example, the corrosion technique enables precise evaluation of vascular architecture [3].

However, the use of corrosion cast studies extends far beyond the vascular system. It is an excellent tool to visualize different types of ducts such as lymphatic vessels [33], genitourinary, or biliary tract [1, 4, 14, 32]. It is sometimes adopted for the assessment of the respiratory system (Fig. 2) and the omental bursa in the abdominal cavity [10].

The first attempts of using this technique are connected with the beginning of anatomy as a modern science. Despite the passage of time, the assumptions of the corrosion technique remain the same [36, 54], but the ways of solving its basic problems are changing, including the effective filling of the structure which is a point of interest for the researcher and full removal of unnecessary tissues surrounding the casting [59]. The precursors of anatomy used natural substances of animal origin as commonly available vascular fillers. Liquid metal infusions were a kind of primary corrosion technique allowing the assessment of 3D structures invisible during traditional anatomical section. However, all such works required the subsequent removal of the residual tissues surrounding

Address for correspondence: Z. Domagała, MD, PhD, Division of Anatomy, Department of Human Morphology and Embryology, Wroclaw Medical University, ul. Chałubińskiego 6a, 50-367 Wrocław, Poland, tel: +48 71 7841331, fax: +48 71 7840079, e-mail: zygmunt.domagala@onet.eu

This article is available in open access under Creative Common Attribution-Non-Commercial-No Derivatives 4.0 International (CC BY-NC-ND 4.0) license, allowing to download articles and share them with others as long as they credit the authors and the publisher, but without permission to change them in any way or use them commercially. 


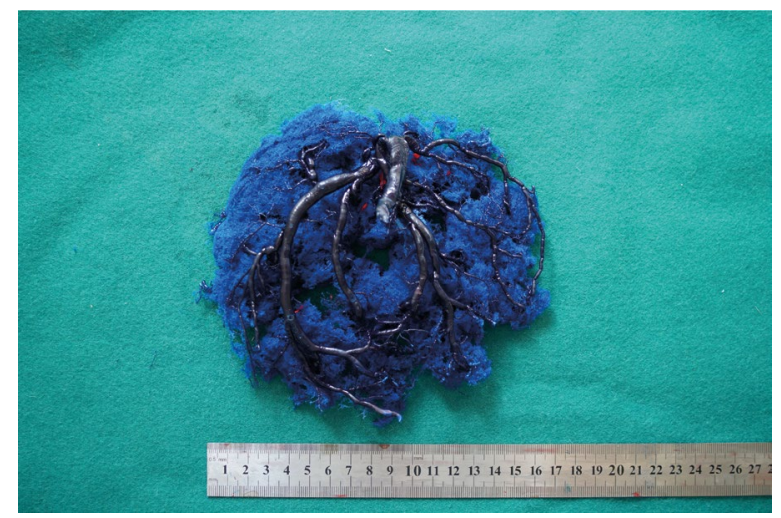

Figure 1. The corrosion cast specimen of human placenta (alkaline maceration).

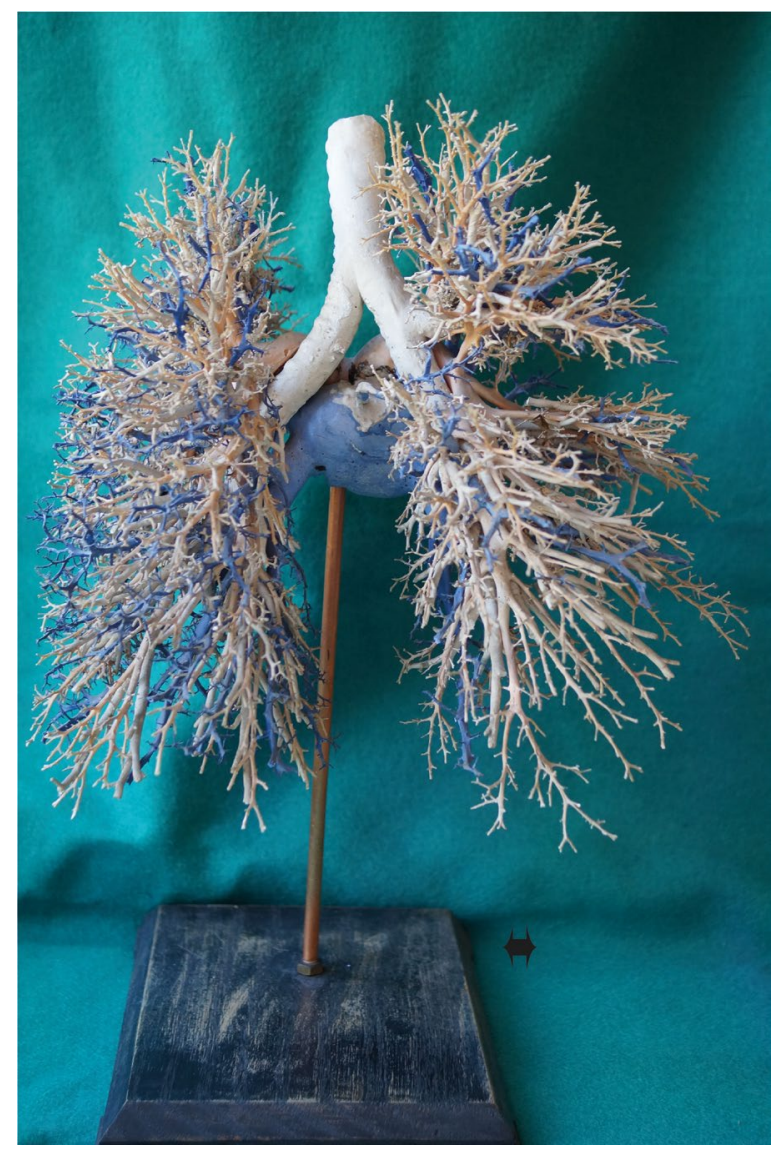

Figure 2. The corrosion cast specimen of human lungs (enzyme maceration); arrow $-1 \mathrm{~cm}$.

the casting. Mechanical peeling of the preparation was most often used, although at times natural mechanisms of body decomposition were used. Thermal agents were also used (multi-hour cooking) as well as other organisms for tissue purification such as fly larvae or ants [38, 42].

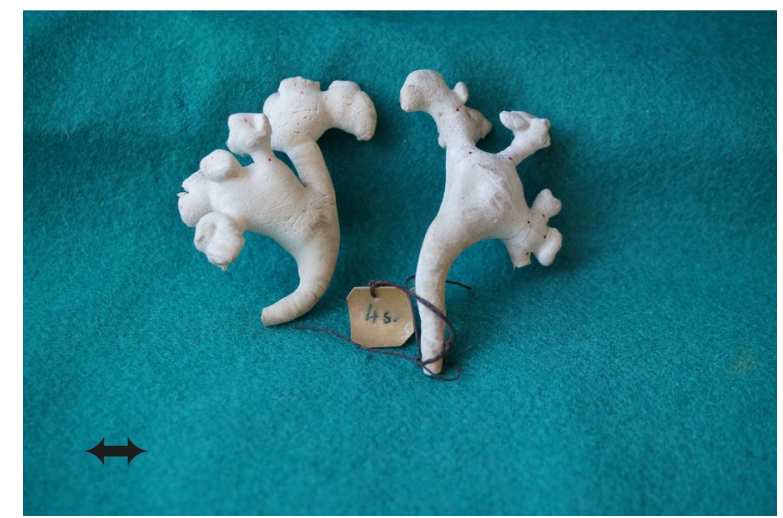

Figure 3. The corrosion cast specimen of human kidney pelvises (acid maceration); arrow $-1 \mathrm{~cm}$.

These classic techniques, however, have one major disadvantage - they do not usually lead to an effective cleaning of the specimen from tissues. On the other hand, mechanical processing of a fine casting carries the risk of damage to the cast itself [6]. Both factors can potentially affect the final value of the corrosive cast specimen (Figs. 1-3). Therefore, the use of an appropriate corrosive medium is essential for the creation of a good-quality product that will remove undesirable tissues surrounding the previously-made casting in the most efficient way.

The ideal corrosive medium should be a universally applicable substance that will fully remove tissues considered undesirable while preserving even the smallest filled anatomical structures, regardless of the injection media that are used. The medium should be relatively cheap, with a high performance rate (so that many preparations can be made in a short time), easy to prepare, characterised by high tissue penetration, controllable (to adjust its activity during the maceration/corrosion process), easy to inactivate or biodegradable so that its use does not involve a high ecological risk (Table 1). The search for the optimal medium has been conducted since the beginning of anatomy as a science. As a result of these efforts, a variety of methods for removing unnecessary tissues during the preparation of a corrosive specimen have been developed. The aim of this article is therefore to compare the usefulness of available tissue maceration techniques during the preparation of anatomical corrosive specimens, as well as an attempt to indicate the best medium for dissolving discarded tissues from the perspective of performing gross - anatomical corrosive specimens. 
Table 1. Ideal corrosive medium — comparison of available corrosion techniques with a perfect hypothetical pattern

\begin{tabular}{|c|c|c|c|c|c|c|}
\hline Feature & Ideal & Cooking & Microwave cooking & Invertebrate & Enzymes & Chemical \\
\hline High tissue penetration & Yes & No & Yes & De & Yes & Yes \\
\hline Versatility & Yes & No & No & No & Yes & $\begin{array}{c}\text { Yes } \\
\text { (depending on the concentration) }\end{array}$ \\
\hline Easy to prepare & Yes & Yes & No & Moderate & No & Moderate \\
\hline Price & Low & Low & High & Low & High & Low \\
\hline Operational speed & Yes & No & Moderate & No & Moderate & $\begin{array}{c}\text { Yes } \\
\text { (depending on the concentration) }\end{array}$ \\
\hline $\begin{array}{l}\text { Ease of disposal/ } \\
\text { /environmental safety }\end{array}$ & Yes & Yes & Yes & No & Yes & $\begin{array}{c}\text { Moderate (acids) } \\
\text { Pretty difficult (alkalis) }\end{array}$ \\
\hline Activity predictability & Complete & Partial & Partial & Low & $\mathrm{DE}$ & Partial \\
\hline $\begin{array}{l}\text { Controllable dynamics } \\
\text { of the process }\end{array}$ & Existing & No & No & No & Yes & $\begin{array}{c}\text { In a very limited way (acids) } \\
\text { No (alkalis) }\end{array}$ \\
\hline Safety for employees & Complete & Yes & Yes & Yes & Yes & $\begin{array}{c}\text { Moderate } \\
\text { (additional protection required) }\end{array}$ \\
\hline Workload & Low & High & High & Moderate & $\begin{array}{l}\text { Moderate (with } \\
\text { proper facilities) }\end{array}$ & $\begin{array}{c}\text { Moderate } \\
\text { Low/moderate }\end{array}$ \\
\hline
\end{tabular}

$\mathrm{DE}$ — difficult to evaluate, versatility (cooperation with various filling substances)

\section{REVIEW OF CORROSIVE TECHNIQUES}

The primary purpose of maceration, when preparing a corrosive specimen, is to remove unwanted material, which is usually the soft tissue surrounding the casting [57]. Depending on the strength of each used agent and/or its time of application, the procedure may result in partial or total removal of retained tissues. Unfortunately, the agent may also damage the cast and/or lead to damage to bone tissue, which in some cases is a frame for the corrosive specimen $[7,23]$. The maceration techniques vary considerably depending on the requirements to which they are applied. It is most often used in forensic medicine to quickly obtain tissues for microscopic examination and for genetic diagnosis [51]. In the case of morphological sciences, the goal is to preserve the injected casting, which means that some techniques with proven effectiveness in forensic medicine may not succeed in morphological sciences.

\section{Cooking}

Cooking is a technique whose assumptions date back to the $15^{\text {th }}-16^{\text {th }}$ century. It consists of placing the specimen of interest in water at a temperature of $100^{\circ} \mathrm{C}$. Nowadays, this method is used properly only when it is necessary to remove soft tissues adhering to the bone. It has been appreciated in anthropology [26]. In anatomy, it can be used for maceration of large structures such as the trachea or bronchi with dedicated resins or silicone [5]. Analysis of the avail- able literature has demonstrated that cooking, as an independent way of removing excessive tissues from the corrosive cast specimen, is of limited usefulness.

Long-term cooking is associated with unpredictable tissue damage. The cooking process itself is time-consuming and relatively dynamic, and may damage the delicate elements of the corrosive specimen, which will reduce its scientific usefulness. Yet, this is only a hypothesis, as the literature has not shown any scientific studies assessing the impact of cooking on the condition of corrosive specimens. It should be added that after boiling the preparation, the remaining tissues should be manually removed, which renders this technique unsuitable for the evaluation of small structures.

\section{Cooking with microwave radiation}

This technique is an extension of the previous method. Its aim is to achieve the same effect in a shorter time, while preserving undamaged DNA from non-macerated tissue, especially bone tissue. Unlike classical cooking, microwave cooking is carried out without the use of water, which reduces uncontrolled damage to the injected structures $[25,49]$. However, the final stage of maceration is also mechanical cleaning of the cooked tissues. This stage greatly limits the usefulness of microwave cooking in morphological sciences.

\section{Maceration with invertebrates}

Currently, the most commonly used living organism for tissue removal in pathology, anthropology, 
and anatomy are Dermestid beetles. Their effectiveness in maceration of soft and mummified tissues has been proven in the literature $[17,58]$. Despite this, the use of these animals to purify corrosive preparations seems to be highly risky. Their massive destructive capability has been demonstrated, which together with the lack of predictability makes this technique difficult to accept from the perspective of performing precise corrosive specimens. Invertebrate germs are an effective tool for maceration of corpses, but the delicate structures of vascular castings will not be sufficient to resist the influence of these living organisms. This technique, according to the study authors, should not be used in morphological sciences but is an interesting alternative to thermal and enzymatic methods in anthropology and forensic medicine [49].

\section{Enzymatic methods}

This technique involves using enzymes that digest proteins, fats, and sugars at a temperature of about $37^{\circ} \mathrm{C}$. Theoretically, such a method should be an effective way of precise purification of tissues that surround a material injected and filled with dedicated agents. In the literature, the following enzymes are used: trypsin, pepsin, and pancreatin [23]. Unfortunately, the number of available works based on this technique is limited. Most of the currently accessible analyses concern the enzymatic maceration of soft tissues in order to purify skeletal material $[13,46]$. Their authors emphasize that the technique causes fast and effective maceration $[52,60]$. This variability of the dynamics of action of enzymatic corrosion lies at the basis of combining the enzymatic technique with the chemical technique [20]. Some authors suggest that the enzymatic maceration technique is perfectly suited for the development of a corrosive specimen [6], whose purpose is to assess the topographical relations between the examined structures and bones. Enzymatic maceration, although more difficult to perform than chemical one, guarantees preservation of bone tissue and enables such observations [15]. Corrosion with enzymatic methods, therefore, has the potential to selectively destruct tissues while leaving others intact. The unique feature of this medium significantly increases the attractiveness of enzymatic maceration as a desirable technique for precise soft tissue cleaning. In addition, it will prospectively enable the creation of "semi-erosion" specimens. Regrettably, there is a lack of reliable comparisons between chemical and enzymatic techniques in the scientific literature; therefore, with the current state of knowledge, it is not possible to recommend any of these techniques as being superior to other techniques listed in this article.

\section{Chemical methods}

Chemical maceration is currently the most commonly used method to eliminate the unwanted tissues surrounding the injected material/casting $[6,35]$. Usually strong caustic aqueous solutions of acids or alkali are used for corrosion. Their use is intended to cause the rapid denaturation of unwanted tissues and facilitate their complete removal. The primary purpose of the use of highly corrosive substances is to avoid the necessity for mechanical removal of remaining tissues after maceration. Heavily corrosive solutions cause so much damage that, after the corrosion process, only water or neutralising solution is required to rinse the specimen [31]. If we compare the effect of both types of corrosive substances on tissues on our account of just few clinical data, we can conclude that a strong base should be a better corrosive agent. Acid usually causes rapid superficial denaturation of tissues, which prevents it from penetrating deeper structures, while alkaline causes rapid development of liquefactive necrosis, making penetration into deeper structures easier $[16,40]$.

\section{Acid corrosive agents}

In the case of tissue dissolution carried out using acids, studies which use either hydrochloric or sulphuric acid dominate the literature. Due to the use of different body parts undergoing corrosion, the authors use different but relatively high concentrations of both acids, which vary from $30 \% \mathrm{HCL}[2$, 53] or $30 \%$ sulphuric acid [48] to as much as $50 \%$ $\mathrm{HCL}[29,41]$. Both compounds are characterised by good water solubility and very strong activity. Despite the fact that the specimens were kept in acid solutions for several days, the necessity of mechanical cleaning of the casting after the procedure was observed $[30,41]$ which is a significant limitation for this technique. This is due to the rapid denaturing of proteins by acids described earlier, and is shown in several clinical studies. This, in our opinion, has a significant impact on the usefulness of the obtained casting. The retention of undissolved or strongly associated with the casting denatured tissues may complicate further scientific analysis of the obtained specimen. 
Table 2. Comparison of the latest works using potassium hydroxide as a medium for dissolving tissues

\begin{tabular}{|c|c|c|c|c|c|c|}
\hline Author & Corrosion area & $\mathrm{KOH}$ & Corrosion time & $\begin{array}{l}\text { Operating } \\
\text { temperature }\end{array}$ & $\begin{array}{l}\text { Postprocessing } \\
\text { procedures }\end{array}$ & Filler \\
\hline Domagała et al., 2020 & $\begin{array}{l}\text { Vessels of the } \\
\text { placenta, human }\end{array}$ & $50 \%$ & $24 \mathrm{~h}$ & RT & $\mathrm{H}_{2} \mathrm{O}$ flushing & BIODUR 20 \\
\hline llić et al., 2018 & $\begin{array}{l}\text { Upper extremity } \\
\text { vessels, human }\end{array}$ & $40 \%$ & 7 days & RT & $\mathrm{H}_{2} \mathrm{O}$ flushing & Methyl methacrylate \\
\hline Polguj et al., 2019 & Bovine testes & $40 \%$ & $24 \mathrm{~h}$ & $40^{\circ} \mathrm{C}$ & $\begin{array}{c}\mathrm{H}_{2} \mathrm{O} \text { flushing } \\
+ \text { detergent and then } \\
\mathrm{H}_{2} \mathrm{O} \text { flushing for } 24 \mathrm{~h}\end{array}$ & Batson no. 17 \\
\hline Scala, 2014 & $\begin{array}{l}\text { Neopallium, } \\
\text { human }\end{array}$ & $30 \%$ & $1-2$ weeks & RT & $\begin{array}{c}\text { Distilled } \\
\mathrm{H}_{2} \mathrm{O} \text { flushing }\end{array}$ & $\begin{array}{l}\text { Methyl methacrylate } \\
\text { (Polysciences) }\end{array}$ \\
\hline Eberlova et al., 2017 & $\begin{array}{l}\text { Various organs, } \\
\text { porcine }\end{array}$ & $15 \%$ & 2-3 days & $40^{\circ} \mathrm{C}$ & $\mathrm{H}_{2} \mathrm{O}$ flushing & BIODUR E20 plus \\
\hline Mazur et al., 2015 & $\begin{array}{l}\text { Heart - coronary } \\
\text { sinus, human }\end{array}$ & $10-15 \%$ & 3 weeks & RT & $3 \%$ trichloric acid & $\begin{array}{l}\text { Duracryl plus (Spofa, } \\
\text { Dental, Czechy) }\end{array}$ \\
\hline $\begin{array}{l}\text { Mazensky and Flesarova, } \\
2017\end{array}$ & $\begin{array}{l}\text { Renal arteries, } \\
\text { Guinea pig }\end{array}$ & $2-4 \%$ & $48 \mathrm{~h}$ & $60-70^{\circ} \mathrm{C}$ & $\mathrm{H}_{2} \mathrm{O}$ flushing & Batson no. 17 \\
\hline Kresakova et al., 2019 & $\begin{array}{l}\text { Liver vessels, } \\
\text { Guinea pig }\end{array}$ & $2-4 \%$ & $3-6$ days & $60-70^{\circ} \mathrm{C}$ & $\begin{array}{l}\mathrm{H}_{2} \mathrm{O} \text { flushing with } \\
\text { fungicide }\end{array}$ & $\begin{array}{l}\text { Methyl methacrylate } \\
\text { (MERCOX-SPI supplies) }\end{array}$ \\
\hline Patzelt et al., 2019 & $\begin{array}{l}\text { Coronary arteries, } \\
\text { porcine heart }\end{array}$ & $7.5 \%$ & $\begin{array}{l}3 \text { days up to } 7 \text { days, } \\
\text { depends on the size } \\
\text { of the specimen* }\end{array}$ & $40^{\circ} \mathrm{C}$ & $\begin{array}{l}\text { Distilled water and then } \\
\text { submerged for } 5-15 \text { min } \\
\text { in } 5 \% \text { formic acid }\end{array}$ & $\begin{array}{c}\text { Mercox-Cl-2B; Ladd } \\
\text { Research, Burlington, } \\
\text { VA }\end{array}$ \\
\hline
\end{tabular}

*Personal communication with dr. Vladimir Musil; RT — room temperature

\section{Corrosion with alkaline solutions}

In the case of alkaline compounds, sodium hypochlorite, sodium hydroxide, and potassium hydroxide are most often used for tissue maceration.

According to King and Birch (2015) [23], sodium hypochlorite is the most popular chemical compound used by anthropologists and pathologists for tissue maceration to cleanse bones of unwanted soft tissues. This is due to its easy availability, low price, intensity of action, and its milder effect on bones than $\mathrm{KOH}$ or $\mathrm{NaOH}$. Moreover, many studies have shown that the use of $10 \%$ NAOCL water solution is effective in cleaning bones without damaging them [50]. However, it should be emphasized that this agent softens tissues rather than dissolves them, so the final stage of maceration must be mechanical removal of the remaining tissues. In the case of fragile bones, foetal material, and specimens that have undergone prior fixation with formalin, the use of sodium hypochlorite may lead to irreversible damage to the examined material. In these circumstances, $\mathrm{Ca}(\mathrm{ClO})_{2}$ or a mixture of $\mathrm{Ca}(\mathrm{ClO})_{2}$ and $\mathrm{Na}_{2} \mathrm{CO}_{3}$ is an alternative with proven safety to such tissues [47]. The majority of morphological studies are conducted on soft tissues. In this case, potassium hydroxide is the most popular corrosive agent in order to prepare a good quality corrosive specimen, which would then be used in scientific analysis. Potassium hydroxide is a very strong alkaline, with strong hygroscopic characteristics, and is perfectly soluble in water, which enables a relatively easy preparation of a working solution of the expected concentration. The usefulness of $\mathrm{KOH}$ solutions in corrosion has been proven in many scientific studies $[11,21,24,27,37,43]$. Different concentrations of $\mathrm{KOH}$ solutions were used, ranging from $60 \%[6,18]$ through $50-40 \%[9,39]$ or $20-10 \%$ [28] to a few per cent solutions $[24,56]$. A comparison of the most recent scientific works using $\mathrm{KOH}$ to perform corrosive cast specimens is presented in Table 2. The corrosion time was influenced by the concentration of the solution, its temperature and size of the dissolved object. In extreme cases, at low $\mathrm{KOH}$ concentrations, this process could take up to 4 weeks.

Sodium hydroxide is an equally popular compound used in chemical maceration. It is a compound with very similar chemical characteristics to potassium hydroxide, characterised by slightly lower hygroscopicity and slightly slower solubility in water. Scientific experiences in using different concentrations of $\mathrm{NaOH}$ for corrosive preparations are lower compared to $\mathrm{KOH}[14,19,30,34,45,55]$. A review of recent works presenting the usefulness of different 
Table 3. The overview of recent scientific works using $\mathrm{NaOH}$ in chemical maceration

\begin{tabular}{|c|c|c|c|c|c|c|}
\hline Author & Organ & Concentration & Etching time & Temperature & Postprocessing & Filling material \\
\hline $\begin{array}{l}\text { Vasconcelos-Filho et al., } \\
2018\end{array}$ & Liver vessels & $6.66 \% *$ & 7 days $(1-15)^{*}$ & RT & Washing in water & $\begin{array}{l}\mathrm{JET}^{\circledR} \text { acrylic methyl meth- } \\
\text { acrylate dental resin }\end{array}$ \\
\hline Esteban et al., 2017 & $\begin{array}{l}\text { Various porcine } \\
\text { organs }\end{array}$ & No data & $\begin{array}{l}\text { From hours to } \\
\text { month }\end{array}$ & RT & Weak acid & $\begin{array}{l}\text { Polyurethane foam, } \\
\text { acrylic resin }\end{array}$ \\
\hline Huling et al., 2019 & Kidney, rat & $20 \%$ & $48 \mathrm{~h}$ & RT & Deionised water & $10 \%$ polycaprolactone \\
\hline Shanthini and Suma, 2019 & Heart, human & $10 \%$ & $72 h$ & $R T$ & Triton-X100 $48 \mathrm{~h}$ & Polyurethane foam \\
\hline Miyake et al., 1996 & $\begin{array}{l}\text { Maxillofacial } \\
\text { area, human }\end{array}$ & $10 \%$ & Few weeks & RT & Distilled water & $\begin{array}{l}\text { Methyl methacrylate resin } \\
\text { (Mercox) }\end{array}$ \\
\hline Noestelthaller et al., 2007 & Heart, dog & No data & $72 \mathrm{~h}$ & RT & Tap water & $\begin{array}{l}\text { Lower-viscosity } \\
\text { acrylic resin (LVAR) }\end{array}$ \\
\hline
\end{tabular}

*Personal communication with prof. J. Vasconcelos-Filho; text in italics. Corrosion of $\mathrm{NaOH}$ was partially ineffective, mechanical removal of denatured tissues was necessary. Significant saponification of the fat tissue surrounding the heart was observed; RT — room temperature

concentrations of $\mathrm{NAOH}$ solutions for dissolution of tissues is summarised in Table 3.

The greatest challenges associated with the use of strong alkalis are the need to prepare $\mathrm{KOH}$ and $\mathrm{NaOH}$ solutions very carefully due to the exothermic process of their dissolution in water. The second potentially dangerous stage is to neutralize the liquid remaining after the corrosion process. The advantage of corrosion with the $\mathrm{KOH} / \mathrm{NaOH}$ technique is the speed of the method and sterility of the obtained castings. $\mathrm{KOH}$ also has the advantage of a large number of valuable scientific publications.

It is worth emphasizing that the use of alkaline solutions with concentration exceeding $40 \%$ in corrosion may promote saponification, which will worsen the quality of the obtained casting, as there will be remains of saponified tissues on the external surface of the prepared material $[6,18,44]$. Such problems were observed when using $50 \% \mathrm{KOH}$ solution when performing the corrosion preparations of the placenta [9]. Therefore, based on our own experience, we recommend using lower than $40 \%$ concentrations of solutions based on potassium hydroxide, even if this will require an extended duration of the procedure itself.

\section{SUMMARY}

Despite the large number of works available that use corrosion techniques for scientific analysis, there is a lack of well-planned, reliable research comparing the effectiveness of various maceration/corrosion techniques for tissues surrounding the casting that is of interest to the researcher. Certainly, the problem of nomenclature is an additional difficulty in conducting a valuable and quick literature review. The procedure defined in the article is typically described in the literature as corrosion, maceration, or dissolution of tissues. It is, in our opinion, worthwhile to use appropriate keywords in the case of preparing a paper that includes corrosive techniques in order to facilitate later evaluation of the text by subsequent generations of scientists.

A critical analysis of the available literature shows a clear advantage of techniques based on chemical maceration (Table 1). Here, it appears that the most effective technique is corrosion using strong alkaline. The attractiveness of this technique results from the low price of chemical substances, relatively high speed of action, unnecessary mechanical removal of remaining tissues, the availability of scientific works describing the maceration technique, and lastly, the high biological safety of the obtained casting. On the other hand, the disadvantages of this technique include the lack of unambiguous standardisation, the risk of bone damage, health risk for the contractor of the corrosion process, and disposal of the remaining solution after the corrosion process. However, it is worth emphasizing the high value of enzymatic corrosion, which, according to our experience, appears to be excellent tool to carry out a more selective corrosion than in the case of the most popular corrosion carried out with strong alkalis.

At present, knowledge about the creation of corrosive preparations is the result of self-experience of a particular team. Each of them uses original ways to obtain the best possible specimens. As each scientist has individual preferences about what technique should be used, it is near impossible to recommend the "best" solution in a clear and easy way. Therefore, in our opinion, it is advisable to conduct research 
comparing the effectiveness of individual methods of tissue maceration at the same time, and in the case of the most popular technique based on the use of strong alkalis, it is advisable to scientifically determine the recommended range of concentrations of solutions used to make castings from different organs and tissues.

\section{Ethical statement}

The authors declare that the study was performed in accordance with the provisions of the World Medical Association Declaration of Helsinki 1964 (with later revisions) and Good Clinical Practice.

\section{Acknowledgements}

According to the new recommendations [22] all authors sincerely thank those who donated their bodies to the science so that anatomical research could be performed. Results from such research can potentially increase mankind's overall knowledge that can then improve patient care. Therefore these donors and their families deserve our highest gratitude.

\section{Funding}

This publication was created as a result of the project entitled "Medical University of Wroclaw as a Regional Centre of Excellence in the field of medical sciences and health sciences" implemented within the funds of the Ministry of Science and Higher Education in the Programme "Regional Initiative of Excellence" in the years 2019-2022, project number 016/RID/2018/19, amount of 11998 121.30 PLN RID.Z501.20.001.

\section{Conflict of interest: None declared}

\section{REFERENCES}

1. Aharinejad S, MacDonald IC, MacKay CE, et al. New aspects of microvascular corrosion casting: a scanning, transmission electron, and high-resolution intravital video microscopic study. Microsc Res Tech. 1993; 26(6): 473-488, doi: 10.1002/jemt.1070260602, indexed in Pubmed: 8305725.

2. An P, Wang Yu, Xing Lm, et al. Fetal complex congenital heart disease diagnosed using prenatal ultrasound and corrosion casting for large vessels: a report for authentic teaching by true representation. Balkan Med J. 2019; 36(5): 296-297, doi: 10.4274/balkanmedj.galenos.2019.2019.6.13, indexed in Pubmed: 31286753.

3. Bereza T, Tomaszewski KA, Bałajewicz-Nowak M, et al. The vascular architecture of the supravaginal and vaginal parts of the human uterine cervix: a study using corrosion casting and scanning electron microscopy. J Anat. 2012;
221(4): 352-357, doi: 10.1111/j.1469-7580.2012.01550.x, indexed in Pubmed: 22844876.

4. Castenholz A. Corrosion cast technique applied in lymphatic pathways. Scan Electron Microsc. 1986(Pt 2): 599-605, indexed in Pubmed: 3797998.

5. Cope LA. Tracheobronchial cast production and use in an undergraduate human anatomy course. Anat Sci Educ. 2008; 1(1): 23-26, doi: 10.1002/ase.7, indexed in Pubmed: 19177375.

6. Cornillie P, Casteleyn C, von Horst C, et al. Corrosion casting in anatomy: Visualizing the architecture of hollow structures and surface details. Anat Histol Embryol. 2019; 48(6): 591-604, doi: 10.1111/ahe.12450, indexed in Pubmed: 31120632.

7. Crouzet C, Fournier H, Papon X, et al. Anatomy of the arterial vascularization of the lips. Surg Radiol Anat. 1998; 20(4): 273-278, doi: 10.1007/BF01628490, indexed in Pubmed: 9787395.

8. Debbaut $C$, Segers $P$, Cornillie $P$, et al. Analyzing the human liver vascular architecture by combining vascular corrosion casting and micro-CT scanning: a feasibility study. J Anat. 2014; 224(4): 509-517, doi: 10.1111/joa.12156, indexed in Pubmed: 24433401.

9. Domagała Z, Domański J, Zimmer A, et al. Methodology of preparation of corrosive specimens from human placenta: A technical note. Ann Anat. 2020; 228: 151436, doi: 10.1016/j.aanat.2019.151436, indexed in Pubmed: 31704147.

10. Doom M, de Rooster $H$, van Bergen $T$, et al. Morphology of the canine omentum. Part 2: the omental bursa and its compartments materialized and explored by a novel technique. Anat Histol Embryol. 2016; 45(1): 28-36, doi: 10.1111/ahe.12167, indexed in Pubmed: 25487433.

11. Eberlova $L$, Liska $V$, Mirka $H$, et al. Porcine liver vascular bed in Biodur E20 corrosion casts. Folia Morphol. 2016; 75(2): 154-161, doi: 10.5603/FM.a2015.0094, indexed in Pubmed: 26542961.

12. Eberlova L, Liska $V$, Mirka $H$, et al. The use of porcine corrosion casts for teaching human anatomy. Ann Anat. 2017; 213: 69-77, doi: 10.1016/j.aanat.2017.05.005, indexed in Pubmed: 28578926.

13. Eriksen AM, Simonsen KP, Rasmussen AR. Conservation of mitochondrial DNA in fast enzyme-macerated skeletal material. Int J Conserv Sci. 2013; 4(2): 127-132.

14. Esteban RJR, McCormick JSL, Prieto DRM, et al. Inyección corrosión, una técnica conocida para el estudio y enseñanza de ductos y estructuras vasculares en anatomía. Int J Morphol. 2017; 35(3): 1147-1153, doi: 10.4067/S071795022017000300053.

15. Frąckowiak $H$, Dębiński $D$, Komosa $M$, et al. The arterial circle of the brain, its branches and connections in selected representatives of the Antilopinae. J Morphol. 2015; 276(7): 766-771, doi: 10.1002/jmor.20377, indexed in Pubmed: 25694115.

16. Hall $A H$, Jacquemin $D$, Henny $D$, et al. Corrosive substances ingestion: a review. Crit Rev Toxicol. 2019; 49(8): 637-669, doi: 10.1080/10408444.2019.1707773, indexed in Pubmed: 32009535.

17. Hall ER, Russell WC. Dermestid beetles as an aid in cleaning bones. J Mammal. 1933; 14(4): 372-374, doi: 10.1093/ jmammal/14.4.372. 
18. Hodde KC, Steeber DA, Albrecht RM. Advances in corrosion casting methods. Scanning Microsc. 1990; 4(3): 693-704, indexed in Pubmed: 2080432.

19. Huling J, Min SI, Kim DS, et al. Kidney regeneration with biomimetic vascular scaffolds based on vascular corrosion casts. Acta Biomater. 2019; 95: 328-336, doi: 10.1016/j. actbio.2019.04.001, indexed in Pubmed: 30953799.

20. Ibba Manneschi L, Zecchi Orlandini S, Faussone Pellegrini MS. The myenteric plexus of the rat colon: a methodological approach for scanning electron microscopical study. Ital J Anat Embryol. 1992; 97(1): 13-22, indexed in Pubmed: 1288444.

21. Ilić $M$, Milisavljević $M$, Maliković $A$, et al. The superficial palmar branch of the radial artery: a corrosion cast study. Folia Morphol. 2018; 77(4): 649-655, doi: 10.5603/ FM.a2018.0033, indexed in Pubmed: 29611162.

22. Iwanaga J, Singh V, Ohtsuka A, et al. Acknowledging the use of human cadaveric tissues in research papers: Recommendations from anatomical journal editors. Clin Anat. 2021 ; 34(1): 2-4, doi: 10.1002/ca.23671, indexed in Pubmed: 32808702.

23. King C, Birch W. Assessment of maceration techniques used to remove soft tissue from bone in cut mark analysis. J Forensic Sci. 2015; 60(1): 124-135, doi: 10.1111/15564029.12582, indexed in Pubmed: 25585666.

24. Kresakova L, Danko J, Andrejcakova Z, et al. 3D reconstruction and evaluation of accessory hepatic veins in right hemilivers in laboratory animals by metrotomography: implications for surgery. Med Sci Monit. 2019; 25: 920-927, doi: 10.12659/MSM.911726, indexed in Pubmed: 30707686.

25. Lee EJ, Luedtke JG, Allison JL, et al. The effects of different maceration techniques on nuclear DNA amplification using human bone. J Forensic Sci. 2010; 55(4): 1032-1038, doi: 10.1111/j.1556-4029.2010.01387.x, indexed in Pubmed: 20384918.

26. Mann RW, Berryman HE. A method for defleshing human remains using household bleach. J Forensic Sci. 2012; 57(2): 440-442, doi: 10.1111/j.1556-4029.2011.01987.x, indexed in Pubmed: 22150429.

27. Mazensky D, Flesarova S. Arrangement of renal arteries in Guinea pig. Anat Rec (Hoboken). 2017; 300(3): 556-559, doi: 10.1002/ar.23496, indexed in Pubmed: 27737510.

28. Mazur M, Walocha K, Kuniewicz M, et al. Application of Duracryl plus for preparation of corrosion casts of venous coronary tree of human heart. Folia Med Cracov. 2015; 55(3): 69-75, indexed in Pubmed: 26774809.

29. Mishra S, Sethi M. A reformed corrosion cast technique using commercially available polyvinyl chloride solution. MAMC J Med Sci. 2015; 1(1): 28, doi: 10.4103/23947438.150058.

30. Miyake M, Ito M, Nagahata S, et al. Morphological study of the human maxillofacial venous vasculature: examination of venous valves using the corrosion resin cast technique. Anat Rec. 1996; 244(1): 126-132, doi: 10.1002/(SICI)10970185(199601)244:1<126::AID-AR13>3.0.CO;2-R, indexed in Pubmed: 8838431.

31. Mulisch M, Ulrich W. Romeis - Mikroskopische Technik. 2015, doi: 10.1007/978-3-642-55190-1. https://link. springer.com/content/pdf/bfm:978-3-642-55190-1/1.pdf.
32. Muñoz ME, Batlouni SR, Vicentini IB, et al. Testicular structure and description of the seminal pathway in Leporinus macrocephalus (Anostomidae, Teleostei). Micron. 2011; 42(8): 892-897, doi: 10.1016/j.micron.2011.06.008, indexed in Pubmed: 21763151.

33. Musiał A, Zarzecki M, Gryglewski R, et al. Ludwik Karol Teichmann (1823-1895). Folia Medica Cracov. 2017; 57(4), doi: $10.24425 / 118114$.

34. Noestelthaller A, Probst A, König HE. Branching patterns of the left main coronary artery in the dog demonstrated by the use of corrosion casting technique. Anat Histol Embryol. 2007; 36(1): 33-37, doi: 10.1111/j.14390264.2006.00711.x, indexed in Pubmed: 17266665.

35. Pálek R, Liška V, Eberlová L, et al. [Experimental processing of corrosion casts of large animal organs]. Rozhl Chir. 2018; 97(5): 222-228, indexed in Pubmed: 29792720.

36. Paluzzi A, Belli $A$, Bain $P$, et al. Brain 'imaging' in the Renaissance. J R Soc Med. 2007; 100(12): 540-543, doi: 10.1177/014107680710001209, indexed in Pubmed: 18065703.

37. Patzelt M, Kachlik D, Stingl J, et al. Morphology of the vasa vasorum in coronary arteries of the porcine heart: A new insight. Ann Anat. 2019; 223: 119-126, doi: 10.1016/j. aanat.2019.02.006, indexed in Pubmed: 30876878.

38. Pevsner J. Leonardo da Vinci's contributions to neuroscience. Trends Neurosci. 2002; 25(4): 217-220, doi: 10.1016/s0166-2236(00)02121-4.

39. Polguj M, Wysiadecki G, Podgórski M, et al. Morphological variations of intra-testicular arterial vasculature in bovine testis: a corrosion casting study. BMC Vet Res. 2015; 11: 263, doi: 10.1186/s12917-015-0580-9, indexed in Pubmed: 26472660.

40. Ramasamy K, Gumaste VV. Corrosive ingestion in adults. J Clin Gastroenterol. 2003; 37(2): 119-124, doi: 10.1097/00004836-200308000-00005, indexed in Pubmed: 12869880 .

41. Rani N, Singh S, Dhar P, et al. Surgical importance of arterial segments of human kidneys: an angiography and corrosion cast study. J Clin Diagn Res. 2014; 8(3): 1-3, doi: 10.7860/JCDR/2014/7396.4086, indexed in Pubmed: 24783063.

42. Riva A, Conti G, Solinas P, et al. The evolution of anatomical illustration and wax modelling in Italy from the 16th to early 19th centuries. J Anat. 2010; 216(2): 209-222, doi: 10.1111/j.1469-7580.2009.01157.x, indexed in Pubmed: 19900181

43. Scala G. Microvasculature of the cerebral cortex: a vascular corrosion cast and immunocytochemical study. Microsc Res Tech. 2014; 77(4): 257-263, doi: 10.1002/jemt.22337, indexed in Pubmed: 24458766.

44. Schatten H. Scanning electron microscopy for the life sciences. Cambridge University Press 2013: doi: 10.1017/ CBO9781139018173.

45. Shanthini S, Suma HY. An innovative method in venous coronary cast technique. Anat Cell Biol. 2019; 52(2): 191-195, doi: 10.5115/acb.2019.52.2.191, indexed in Pubmed: 31338236.

46. Simonsen KP, Rasmussen AR, Mathisen $P$, et al. A fast preparation of skeletal materials using enzyme maceration. J Forensic Sci. 2011; 56(2): 480-484, doi: 
10.1111/j.1556-4029.2010.01668.x, indexed in Pubmed: 21342190

47. Snyder RG, Burdi A, Gaul G. A rapid technique for preparation of human fetal and adult skeletal material. J Forensic Sci. 1975; 20(3): 576-580, indexed in Pubmed: 239090.

48. De Sordi N, Bombardi C, Chiocchetti R, et al. A new method of producing casts for anatomical studies. Anat Sci Int. 2014; 89(4): 255-265, doi: 10.1007/s12565-014-0240-3, indexed in Pubmed: 24788383.

49. Steadman DW, DiAntonio LL, Wilson JJ, et al. The effects of chemical and heat maceration techniques on the recovery of nuclear and mitochondrial DNA from bone. J Forensic Sci. 2006; 51(1): 11-17, doi: 10.1111/j.15564029.2005.00001.x, indexed in Pubmed: 16423217.

50. Stephens BG. A simple method for preparing human sketetal material for forensic examination. J Forensic Sci. 1979; 24(3): 660-662, indexed in Pubmed: 541632.

51. Töro K, Kiss M, Szarvas V, et al. Post mortem introduction of corrosion cast method after coronary stent implantation. Forensic Sci Int. 2007; 171(2-3): 208-211, doi: 10.1016/j. forsciint.2007.02.017, indexed in Pubmed: 17368994.

52. Uhre ML, Eriksen AM, Simonsen KP, et al. Enzymatic maceration of bone: a gentler technique than boiling. Med Sci Law. 2015; 55(2): 90-96, doi: 10.1177/0025802414532246, indexed in Pubmed: 24812061.

53. Uršič M, Vrecl M, Fazarinc G. Corrosion cast study of the canine hepatic veins. Folia Morphol. 2014; 73(4): 475-481, doi: 10.5603/FM.2014.0071, indexed in Pubmed: 25448906 .
54. Van Hee R, Wells FC, Ballestriero R, et al. The art of human anatomy: Renaissance to 21 st century. Vesalius. 2014; 20(1): 25-29, indexed in Pubmed: 25181778.

55. Vasconcelos-Filho JOM, Pereira AH, Pitta GBB, et al. Measurements between the hepatic veins and portal venous system, in human cirrhotic liver: a cast study. Surg Radiol Anat. 2018; 40(4): 395-400, doi: 10.1007/s00276-0171909-9, indexed in Pubmed: 28889187.

56. Walocha JA, Litwin JA, Miodoński AJ. Vascular system of intramural leiomyomata revealed by corrosion casting and scanning electron microscopy. Hum Reprod. 2003; 18(5): 1088-1093, doi: 10.1093/humrep/deg213, indexed in Pubmed: 12721189.

57. Walocha JA, Miodoński AJ, Nowogrodzka-Zagórska M, et al. Application of a mixture of glycol polyethylenes for the preparation of microcorrosion casts: an observation. Folia Morphol. 2002; 61(4): 313-316, indexed in Pubmed: 12725503.

58. Williams SL, Rogers SP. Effects of initial preparation methods on dermestid cleaning of osteological material. Collection Forum. 1989; 5(1): 11-16.

59. Yin G, Chen M, Li J, et al. Vascular corrosion casting of normal and pre-eclamptic placentas. Exp Ther Med. 2017; 14(6): 5535-5539, doi: 10.3892/etm.2017.5207, indexed in Pubmed: 29285088.

60. Yin L, Venkatesan S, Kalyanasundaram S, et al. Influence of enzymatic maceration on the microstructure and microhardness of compact bone. Biomed Mater. 2010; 5(1): 15006, doi: 10.1088/1748-6041/5/1/015006, indexed in Pubmed: 20071762. 